\title{
Evaluation of Vitamin D Levels in Patients with Breast Cancer- related Lymphedema: An Observational Cross-sectional Study
}

\author{
Meme Kanseri illişkili Lenfödem Hastalarında Vitamin D Düzeylerinin Değerlendirilmesi: \\ Kesitsel Gözlemsel Araştırma \\ (1) Didem Sezgin Özcan, (1) Meltem Dalyan*, (1) Serhat Ergül**, (1) Sibel Ünsal Delialioğlu*, \\ (1) Belma Füsun Köseoğlu***
}

\author{
Istanbul Medipol University Faculty of Medicine, Department of Physical Medicine and Rehabilitation, Istanbul, Turkey \\ ${ }^{*}$ Ankara Physical Medicine and Rehabilitation Training and Research Hospital, Clinic of Physical Medicine and Rehabilitation, Ankara, Turkey \\ **Diyarbakır Gazi Yaşargil Training and Research Hospital, Clinic of Physical Medicine and Rehabilitation, Diyarbakır, Turkey \\ ***TOBB ETU Faculty of Medicine, Department of Physical Medicine and Rehabilitation, Ankara, Turkey
}

\section{Abstract}

Objective: The aim of our study was to compare plasma vitamin D levels between patients with breast cancer-related lymphedema (BCRL) and healthy population, and also to investigate the effects of socio-demographic and clinical factors and lymphedema severity on vitamin $D$ levels.

Materials and Methods: Eighty patients with BCRL [mean age 55.5 \pm 8.9 (36-81)] and age- and sex-matched 80 healthy controls [mean age $53.7 \pm 7.4(32-70)]$ who were not on calcium or vitamin D supplementation were included in the study. Socio-demographic and clinical characteristics of the subjects were questioned. Plasma 25-Hydroxyvitamin D3, calcium, phosphorus, alkaline phosphatase (ALP), and parathormone (PTH) levels were evaluated. Lymphedema was classified as stage 0, I, II, or III.

Results: The mean duration of lymphedema was $23.5 \pm 13.8$ months. Comparisons revealed lower vitamin D levels and higher PTH and ALP levels in patients with BCRL than healthy controls. As a result of multivariate regression analysis, a significant relationship was revealed between vitamin D levels and age, breast cancer stage, and disease duration in patients with BCRL. Vitamin D levels were significantly lower and PTH levels were significantly higher in stage 3 lymphedema patients compared to stage 1.

Conclusion: Vitamin D levels were detected lower in patients with lymphedema than healthy controls. Although vitamin D levels were found to be lower in patients with severe lymphedema, the multivariate regression analysis revealed that the severity of lymphedema does not have a significant effect on vitamin D levels.

Keywords: Vitamin D, breast cancer, lymphedema, parathormone

\section{Öz}

Amaç: Çalışmamızın amacı meme kanseri ile ilişkili lenfödem (MKiL) ve sağlıkı popülasyondaki hastalarda plazma D vitamini düzeylerini karşılaştırmak ayrıca sosyo-demografik ve klinik faktörlerin ve lenfödem şiddetinin $D$ vitamini düzeylerine etkilerini tespit etmekti.

Gereç ve Yöntem: MKiL'li 80 hasta [yaş ortalaması 55,5 $\pm 8,9$ (36-81)] ve kalsiyum ya da Vitamin D tedavisi altında olmayan 80 yaş ve cinsiyet

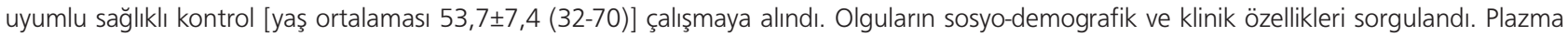
25-Hydroxyvitamin D3, kalsiyum, fosfor, alkalen fosfataz (ALP), parathormon (PTH) düzeyleri değerlendirildi. Lenfödem evre 0, I, II veya III olarak sınıflandırıldı.

Bulgular: Ortalama lenfödem süresi $23,5 \pm 13,8$ aydı. MKiL'li hastalarda sağlıklı kontrollere oranla daha düşük $D$ vitamini düzeyleri ve daha yüksek PTH ve ALP düzeyleri saptandı. Çok değişkenli regresyon analizi sonucunda, MKIL hastalarında D vitamini düzeyleri ile yaş, meme kanseri evresi ve hastalık süresi arasında anlamlı bir ilişki olduğu ortaya çıkarıldı. Evre 3 lenfödem hastalarında, evre 1'e kıyasla D vitamini düzeyi daha düşük ve PTH düzeyi anlamlı olarak daha yüksekti.

Sonuç: D vitamini düzeyleri lenfödemli hastalarda sağlıklı kontrollere oranla daha düşük saptanmıştı. Şiddetli lenfödemi olan hastalarda D vitamini düzeylerinin daha düşük saptanmasına rağmen, çok değişkenli regresyon analizi lenfödem şiddetinin D vitamini düzeyleri üzerinde anlamlı bir etkisi olmadığını ortaya koymuştur.

Anahtar kelimeler: D vitamini, meme kanseri, lenfödem, parathormon

Address for Correspondence/Yazıșma Adresi: Didem Sezgin Özcan MD, İstanbul Medipol University Faculty of Medicine, Department of Physical Medicine and Rehabilitation, İstanbul, Turkey Phone: +90 2124607777 E-mail: sezgindidem@gmail.com ORCID ID: orcid.org/0000-0003-0246-3001

Received/Geliş Tarihi: 07.05.2019 Accepted/Kabul Tarihi: 01.10.2019

${ }^{\circ}$ Copyright 2019 by the Turkish Osteoporosis Society

Turkish Journal of Osteoporosis published by Galenos Publishing House. 


\section{Introduction}

Vitamin $D$ has an essential role to maintain healthy bone structure and muscle function. Sufficient serum level of 1.25 dihydroxy vitamin D3 [1.25 (OH)2D3], which is the major determinant of calcium (Ca) absorption, is important for bone mineralization (1). Vitamin D deficiency is a highly prevalent condition worldwide (2). The risk factors include age, body mass index, conservative dressing style, sunscreen use, reduced sun exposure, less outdoor time, skin tone and geographic location (3-5). The primary origin of vitamin $D$ is photoproduction in the skin following ultraviolet B exposure. Vitamin D3 is transported to the liver with vitamin $D$ binding protein (DBP) and hydroxylated by 25-hydroxylase to form 25 hydroxyvitamin D3 [25(OH) D3]. Afterwards, 25(OH) D3 is transported to the kidney and converted to $1.25(\mathrm{OH}) 2 \mathrm{D} 3$ by $1 \alpha$-hydroxylase. $1.25(\mathrm{OH}) 2 \mathrm{D} 3$ (calcitriol) is the biologically active form of the hormone and regulates serum $\mathrm{Ca}$ and phosphorus (P) concentrations for essential cellular functions and supports the mineralization of the bone $(1,5,6)$. However, in recent years the number of researches focused on the extraskeletal functions of vitamin D were increased. Vitamin D deficiency has been associated with the increased risk of diabetes mellitus, obesity, cardiovascular diseases, infections, asthma, inflammatory bowel disease, several neurological diseases, and cancers (7).

Several studies also demonstrated that vitamin $D$ had potential role in cancer prevention and progression (8-11). A metaanalysis conducted by Wang et al. (12) revealed that the active form of vitamin $D$ level was inversely correlated with the risk of breast cancer. Another meta-analysis for impact of vitamin D on cancer outcome revealed that higher levels of vitamin D provided lower risk of mortality in breast cancer patients (13). The bioactive form of vitamin $D$ has favorable effects against cancer by stimulation of apoptosis and cell differentiation, and by inhibition of inflammation, cell proliferation, and angiogenesis. It is possible that vitamin D also plays role in preventing the invasion and metastasis of the cancer cells $(7,14,15)$. It is also shown that chemotherapy is associated with reduced serum vitamin D levels (5). In a recent study, PinedaMoncusi et al. (16) demonstrated that patients with breast cancer had reduced $25(\mathrm{OH})$ D levels particularly after recent chemotherapy. Over long term, it had partially recovered but still remained lower compared to healthy population.

Today, the 5-years survival rate for breast cancer is up to $90 \%$ due to the improvements in cancer treatment (17). Breast cancer survivors are at risk for long-term complications such as breast cancer-related lymphedema (BCRL). It is characterized by the accumulation of protein-rich lymphatic fluid in the interstitial spaces which leads to swelling of the subcutaneous tissue. Lymph node dissection and/or radiotherapy can lead to damage to the lymphatic system which causes blockage of the lymphatic fluid passages and almost $40 \%$ of the patients may eventually develop lymphedema (18). It has previously shown that lymphedema has a negative impact on patient's quality of life and causes elevated rates of anxiety, depression and physical impairment compared to breast cancer survivors without lymphedema $(19,20)$. Patients with lymphedema or at risk of developing lymphedema are also advised several precautions. Applying sunscreen, avoiding being outside during the hottest hours of the day and excessive sun exposure are some of them (21). These recommendations mentioned above and reduced outdoor time due to the psychological distress and physical impairment may affect the vitamin D levels negatively in patients with lymphedema. In this study we aimed first; to compare serum vitamin D levels in patients with BCRL and healthy population, second; to determinate the socio-demographic and clinical risk factors affecting vitamin $D$ levels in patients with $B C R L$, third; to investigate the impact of lymphedema severity on vitamin $\mathrm{D}$ levels.

\section{Materials and Methods}

A total of one hundred consecutive patients with the diagnosis of BCRL were evaluated in the lymphedema follow-up clinic between June 2012 and May 2013. Subjects who have $\geq 2 \mathrm{~cm}$ difference in circumferential measurements or a $200 \mathrm{~mL}$ limb volume difference between the extremities evaluated as BCRL. Data from adults $>18$ years who had a history of breast cancer treatment at least 3 months ago were included. Patients who had history of any disease or drug use which might affect the metabolism of vitamin D (alcoholism, chronic liver or kidney failure, malabsorption syndromes, inflammatory bowel disease, tuberculosis or anticonvulsant medication) were excluded from the study. Among the 100 patients with the diagnosis of BCRL, 4 patients had chronic liver disease, 6 had kidney disease, 4 had known parathyroid adenoma and 6 patients had the use of anticonvulsant drugs for neuropathic pain. Therefore 20 patients excluded from the study group and consequently 80 patients with BCRL were eligible for the study. Eighty age and sex-matched healthy controls who were not on $\mathrm{Ca}$ and vitamin D supplementation were also included in the study for further comparisons. Our study was approved by the local ethics committee and informed consent was obtained from all participants.

Socio-demographic (age, body mass index, educational status, work status) and clinical characteristics of the lymphedema patients (disease duration, pathological features, breast cancer grade, treatment with chemotherapy and radiotherapy, duration of lymphedema, stage of lymphedema, presence of systemic disease, previous use of vitamin D) were questioned and recorded.

\section{Laboratory Evaluation}

Serum $25(\mathrm{OH})$ D3 concentrations were determined by the chemiluminescence microparticle immunoassay technology by Architect i2000 (Abbott, Germany) device. A serum level of more than $29 \mathrm{ng} / \mathrm{mL}$ was evaluated as normal, $20-29 \mathrm{ng} / \mathrm{mL}$ as insufficient and lower than $20 \mathrm{ng} / \mathrm{mL}$ as deficient (22). The serum vitamin $D$ levels were measured in autumn and summer 
seasons in both BCRL and control groups in order to minimize the seasonal difference. Ca, P, alkaline phosphatase (ALP), parathormone (PTH), kidney and liver function tests were also evaluated.

\section{Lymphedema Classification}

Lymphedema is classified as stage $0, \mathrm{I}, \mathrm{II}$, or III. stage 0 lymphedema is a preclinical stage in which the patient has the potential for developing lymphedema. Visible pitting edema exists in Stage I and it can be reduced with limb elevation. In stage II, the volume of the edema increases and the structure becomes firmer due to the fibrosis. The swelling can't be reduced with the limb elevation. Stage III is characterized with extremely swollen and thickened tissue usually accompanied by skin changes such as papules and open draining wounds (23). Statistical Analysis

SPSS version 20.0 (SPSS Inc., Chicago, IL, USA) was performed for the statistical analyses. Distributions of continuous variables were evaluated by the Shapiro-Wilk test. For the continuous variables mean \pm standard deviation was used for determination, median (minimum - maximum) was used for discrete variables and number (n) and percentage (\%) were used for categorical variables. The significance of the difference in mean values between two groups was analyzed with Student's t-test, and analyzed with one way ANOVA for more than two groups. Multivariate regression analysis is used to investigate the clinical and socio-demographical factors affecting vitamin $D$ levels in patients with BCRL. A p-value of $<0.05$ was evaluated as statistically significant.

\section{Results}

Eighty patients with BCRL [mean age $55.5 \pm 8.9$ (36-81)] and 80 age and sex-matched healthy control [mean age 53.7 \pm 7.4 (32-70)] were included in the study. All patients in both groups were female. The mean duration of lymphedema in patients with BCRL was $23.5 \pm 13.8$ months. Twenty-four of the patients had stage 1, 42 of the patients had stage 2 and 14 of them had stage 3 lymphedema. The socio-demographic and clinical characteristics of the patients were demonstrated in Table 1. Between-group comparisons revealed lower vitamin $D$ levels and higher PTH and ALP levels in patients with BCRL (Table 2). Only 29 (36.2\%) of the patients with BCRL have been evaluated in terms of serum vitamin D levels in the last 6 months and only $21(26.3 \%)$ of the patients used vitamin D replacement therapy. Eleven $(13.7 \%)$ of the patients had the history of osteoporosis and the number of patients who were still on bisphosphonate therapy was 5 (6.2\%). Among the lymphedema patients; 12 (\%15) of them had normal ranges of vitamin D, 20 (25\%) of them had deficient and 48 (\%60) of them had insufficient vitamin D levels. We also performed a multivariate regression analysis to investigate clinical and socio-demographic factors affecting vitamin $\mathrm{D}$ levels in patients with lymphedema. The analysis revealed a significant relation between vitamin $D$ levels and age, the grade of breast cancer and disease duration ( $F$

\begin{tabular}{|c|c|}
\hline Variables & $n=80$ \\
\hline Age, years & $55.5 \pm 8.9(36-81)$ \\
\hline Sex, female & $80(100)$ \\
\hline $\mathrm{BMI}, \mathrm{kg} / \mathrm{m}^{2}$ & $30.5 \pm 5.3$ \\
\hline $\begin{array}{l}\text { Educational status } \\
\text { illiterate } \\
\text { Low } \\
\text { High } \\
\text { Work status } \\
\text { Working } \\
\text { Not-working }\end{array}$ & $\begin{array}{l}11(13.7) \\
37(46.3) \\
32(40) \\
18(22.5) \\
62(77.5)\end{array}$ \\
\hline $\begin{array}{l}\text { Pathology } \\
\text { Invazive ductal } \\
\text { Infiltrative lobular } \\
\text { Breast cancer gr } \\
\text { Grade } 1 \\
\text { Grade } 2 \mathrm{a} / 2 \mathrm{~b} \\
\text { Grade } 3 \mathrm{a} \\
\text { Grade } 4 \\
\text { Chemotherapy } \\
\text { Radiotherapy }\end{array}$ & $\begin{array}{l}68(85) \\
12(15) \\
10(12.5) \\
31(38.8) \\
23(28.7) \\
16(20) \\
79(98.7) \\
59(73.8)\end{array}$ \\
\hline Disease duration, months & $55.8 \pm 28.8$ \\
\hline $\begin{array}{l}\text { Lymphedema duration, months } \\
\text { Lymphedema stage } \\
\text { Stage } 1 \\
\text { Stage } 2 \\
\text { Stage } 3\end{array}$ & $\begin{array}{l}23.5 \pm 13.8 \\
24(30) \\
42(52.5) \\
14(17.5)\end{array}$ \\
\hline Vitamin D levels, ng/mL & $14.3 \pm 8.7$ \\
\hline $\begin{array}{l}\text { Normal } \\
\text { Insufficiency } \\
\text { Deficiency }\end{array}$ & $\begin{array}{l}5(6.3) \\
19(23.7) \\
56(70)\end{array}$ \\
\hline Parathormon (pg/mL) & $63.2 \pm 18.4$ \\
\hline Calcium (mg/dL) & $10.5 \pm 5.3$ \\
\hline Phosphorus (mg/dL) & $3.8 \pm 1.9$ \\
\hline Alkaline phosphatase (IU/L) & $79.8 \pm 18.9$ \\
\hline \multicolumn{2}{|c|}{$\begin{array}{l}\text { BMI: Body mass index, Vitamin D Deficiency: }<20 \mathrm{ng} / \mathrm{mL} \text {, Insufficiency: } 21-29 \\
\mathrm{ng} / \mathrm{mL} \text {, normal: }>30 \mathrm{ng} / \mathrm{mL} \text {, Values are mean } \pm \mathrm{SD} \text { and } \mathrm{n}(\%)\end{array}$} \\
\hline
\end{tabular}

$(6.5)=5.160 ; p=0.04$ ) (Table 3). BCRL patients were divided into 3 groups according to the severity of lymphedema and there were significant differences in stage 3 lymphedema compared to stage 1 in terms of vitamin D and PTH levels (Table 4).

\section{Discussion}

Vitamin D deficiency is widely seen all over the world, and in recent years studies have examined its extra-skeletal effects. There are also many studies evaluated the relationship between breast cancer and vitamin $D(12,16,24-29)$. It is claimed that vitamin $\mathrm{D}$ deficiency may contribute to breast cancer development and is related with poor prognosis. It is also suggested that cancer and cancer treatment may cause a decrease in vitamin $D$ levels. The aim of our study was to compare vitamin $D$ levels between patients with BCRL and 
healthy controls, and to determine the effects of the severity of lymphedema and other factors on vitamin D levels. As a result, we demonstrated that vitamin D levels were significantly lower in patients with BCRL and; the increase in age, duration of disease and grade of breast cancer were related with reduced vitamin D levels. We also revealed that vitamin D levels were lower and PTH levels were higher in patients with severe lymphedema than mild lymphedema.

In the literature, the studies investigating the relation of vitamin $\mathrm{D}$ and breast cancer are mostly about whether vitamin

\begin{tabular}{|c|c|c|c|}
\hline Variables & $\begin{array}{l}\text { Lymphedema } \\
\text { patients } \\
\mathrm{n}=\mathbf{8 0}\end{array}$ & $\begin{array}{l}\text { Control } \\
\text { group } \\
\mathrm{n}=\mathbf{8 0}\end{array}$ & p \\
\hline Age, years & $55.5 \pm 8.9$ & $53.7 \pm 7.4$ & 0.16 \\
\hline BMI, kg/mw2 & $30.5 \pm 5.3$ & $29.4 \pm 5.1$ & 0.22 \\
\hline $\begin{array}{l}\text { Vitamin D levels, ng/ } \\
\mathrm{mL} \\
\text { Normal } \\
\text { Deficiency } \\
\text { Insufficiency }\end{array}$ & $\begin{array}{l}14.3 \pm 8.7 \\
12(15) \\
20(25) \\
48(60)\end{array}$ & $\begin{array}{l}21.8 \pm 9.7 \\
17(21.3) \\
30(37.5) \\
33(41.2)\end{array}$ & 0.02 \\
\hline Parathormon (pg/mL) & $63.2 \pm 18.4$ & $49.4 \pm 18.7$ & 0.01 \\
\hline $\begin{array}{l}\text { Calcium }(\mathrm{mg} / \mathrm{dL}) \\
\text { Phoshorus }(\mathrm{mg} / \mathrm{dL}) \\
\text { Alkaline phosphatase } \\
(\mathrm{IU} / \mathrm{L})\end{array}$ & $\begin{array}{l}10.5 \pm 5.3 \\
3.8 \pm 1.9 \\
79.8 \pm 18.9\end{array}$ & $\begin{array}{l}9.4 \pm 3.4 \\
6.2 \pm 2.26 \\
64.06 \pm 20.1\end{array}$ & $\begin{array}{l}0.47 \\
0.10 \\
0.01\end{array}$ \\
\hline \multicolumn{4}{|c|}{$\begin{array}{l}\text { BMI: Body mass index } \\
\text { Values are mean } \pm \text { SD and } n(\%) \text {, Significance at } p<0.05\end{array}$} \\
\hline
\end{tabular}

Table 3. Multivariate regression analysis for the factors affecting vitamin D levels

\begin{tabular}{|l|l|l|l|}
\hline Variables & R2 & Constant & $\mathbf{p}$ \\
\hline Age & 0.86 & -0.38 & 0.04 \\
\hline Breast cancer grade & - & -3.34 & 0.007 \\
\hline Disease duration & - & -0.57 & 0.02 \\
\hline Lymphedema duration & - & 0.43 & 0.09 \\
\hline Lymphedema stage & - & 1.65 & 0.08 \\
\hline
\end{tabular}

D was a risk factor in the development of breast cancer (2426). Circulating $25(\mathrm{OH}) \mathrm{D} 3$ is combined with vitamin-DBP and transferred into normal breast cells. Vitamin $D$ interacts with many genes such as VDR, CYP27B1, CYP24A1, and megalin. The proper functioning of this cycle is important in the differentiation of the cells. Any failure in this chain has been suggested to contribute to the development and progression of breast cancer $(25,26)$. In our study, we found that serum vitamin $D$ levels were lower in patients with BCRL compared to healthy controls. The decrease in vitamin $D$ levels may be caused by several factors. As suggested by the previous studies the hypothesis of 'previous low levels of vitamin D increases the risk of cancer development' may be the reason for our result. The negative effects of cancer treatments (especially chemotherapy) on vitamin D levels may also be a reason (5). In addition, we consider that various negative conditions caused by lymphedema might also affect the vitamin D levels.

Isenring et al. (5) suggested that cancer treatments were associated with low vitamin D status because of the treatmentrelated fatigue, decreased time spent outdoors, dietary changes and sun avoidance. Another reason for low vitamin D levels in patients receiving chemotherapy is the conversion of vitamin D to inactive form due to upregulation of cytochrome P450 enzymes. Chemotherapy may also cause hepatotoxicity and the acute phase response leading lower levels of albumin and DBP $(5,30)$. In another study, Pineda-Moncusi et al. (16) compared vitamin $D$ levels with healthy controls. And they revealed that patients who underwent recent chemotherapy had the lowest levels of $25(\mathrm{OH})$ D3. They explained this result with photosensitivity effect of chemotherapy which causes reduction of sunlight exposure. They also demonstrated that $25(\mathrm{OH}) \mathrm{D} 3$ levels partially recovered in long-term patients but the values stayed under the levels of the healthy controls. The reason of this result couldn't explained clearly but they suggested that genetic or physiological factors might cause lower vitamin D levels in patients with breast cancer (16).

$\mathrm{BCRL}$ is an important complication in breast cancer survivors and leads to deteriorations in upper extremity functions and quality of life (31-33). In our study, several negative conditions

Table 4. The comparisons of laboratory results among the severity of lymphedema

\begin{tabular}{|c|c|c|c|c|}
\hline Variables & $\begin{array}{l}\text { Stage } 1 \text { lymphedema } \\
\mathrm{n}=\mathbf{2 4}\end{array}$ & $\begin{array}{l}\text { Stage } 2 \text { lymphedema } \\
\mathrm{n}=42\end{array}$ & $\begin{array}{l}\text { Stage } 3 \text { lymphedema } \\
\mathrm{n}=14\end{array}$ & $\mathbf{p}$ \\
\hline Age & $54.3 \pm 10.9$ & $58.0 \pm 10.9$ & $53.5 \pm 9.2$ & 0.84 \\
\hline BMI & $27.6 \pm 5.3$ & $31.5 \pm 3.1$ & $34 \pm 2.4$ & 0.32 \\
\hline Vitamin D levels, ng/mL & $17.3 \pm 6.5$ & $14.3 \pm 6.2$ & $10.7 \pm 5.4$ & $0.02^{*}$ \\
\hline Parathormon, pg/mL & $51.1 \pm 13.1$ & $66.8 \pm 14.6$ & $79.8 \pm 18.5$ & $0.04^{*}$ \\
\hline Calcium, mg/dL & $9.5 \pm 1.35$ & $11.3 \pm 2.1$ & $9.2 \pm 0.7$ & 0.22 \\
\hline $\begin{array}{l}\text { Phosphorus, mg/dL } \\
\text { Alkaline phosphatase, IU/L }\end{array}$ & $\begin{array}{l}3.6 \pm 0.6 \\
74.0 \pm 18.7\end{array}$ & $\begin{array}{l}3.7 \pm 0.5 \\
81.6 \pm 21.5\end{array}$ & $\begin{array}{l}4.1 \pm 1.2 \\
73.8 \pm 17.6\end{array}$ & $\begin{array}{l}0.57 \\
0.52\end{array}$ \\
\hline
\end{tabular}


associated with lymphedema may have contributed to the lower levels of vitamin D. To the best of our knowledge, in the literature, among to the studies about breast cancer and vitamin $D$; there is no other study evaluating patients with lymphedema and also the effects of lymphedema on vitamin D levels. In our study, we demonstrated that patients with severe lymphedema (stage 3) had lower levels of vitamin D than mild lymphedema (stage 1). Several factors might cause this result. It has previously shown that higher levels of psychological distress existed in patients with lymphedema which may reduce the outdoor time and sun exposure (34). In addition, precautions given to this patient group including avoidance of being outside at the hottest hours of the day and application of sun-screen might also affect the results. These recommendations help to avoid excessive sunlight exposure to prevent the increase in blood flow and lymphatic load caused by heat. Applying sunscreen is also useful in preventing superficial burns which can cause inflammation, vasodilatation, and infection $(21,35)$. These reasons might contribute to the reduced vitamin $D$ synthesis especially in patients with severe lymphedema.

In our study, we also revealed that $60 \%$ of the lymphedema patients had vitamin D insufficiency and 25\% had vitamin D deficiency. In the literature, Hsieh et al. (36) evaluated the vitamin $\mathrm{D}$ levels in breast cancer survivors and they demonstrated that $58.2 \%$ of them had deficient and $35.2 \%$ had insufficient levels consisted with our study. In our study, only $15 \%$ of the lymphedema patients had adequate vitamin $D$ levels, but only $36.2 \%$ of the patients were evaluated for serum vitamin D levels in the last 6 months. Among this population, only $26.3 \%$ of the BCRL patients have received vitamin $D$ replacement therapy. These results may show that vitamin $D$ levels were not taken into account and treated adequately in this patient group. Considering the increased risk of getting new breast cancer in this population, although it is not fully supported in the literature, keeping vitamin D levels at normal levels may be beneficial (37).

In our study, we also identified socio-demographic and clinical factors related to vitamin D levels among patients with lymphedema. The multivariate regression analysis revealed significant relations between vitamin $D$ levels and age, the grade of breast cancer and disease duration. Although lower levels of vitamin D demonstrated in patients with severe lymphedema, the multivariate analysis didn't reveal significant effect of the severity of lymphedema. In the literature, Shin et al. (29) identified the determinants for $25(\mathrm{OH}) \mathrm{D}$ in Korean breast cancer survivors and they observed that time from diagnosis, vitamin D and other supplementations, the season of the blood sampling, smoking, and the number of parity were related with the serum $25(\mathrm{OH}) \mathrm{D}$ levels.

\section{Study Limitations}

Our study was a cross-sectional study, and does not provide cause and effect relationships. In addition, this study did not include information about psychological status, quality of life, outdoor spent-time or amount of the dietary intake of the vitamin D of the participants. Thus we couldn't do inter or intragroup comparisons among these variables. Another important limitation of this study was not including a third group having breast cancer but without lymphedema.

\section{Conclusion}

In this study, we demonstrated that vitamin $D$ levels were lower in patients with BCRL compared to healthy population. We also revealed that patients with severe lymphedema had lower levels of vitamin D compared to mild lymphedema. Future studies including larger study population and more detailed information among lymphedema patients such as sun exposure time, dietary intake and psychological status are needed.

\section{Ethics}

Ethics Committee Approval: The study were approved by the Ankara Physical Therapy and Rehabilitation Training and Research Hospital of Local Ethics Committee (protocol number: 2321).

Informed Consent: Consent form was filled out by all participants.

Peer-review: Externally and internally peer-reviewed.

Authorship Contributions

Concept: D.S.Ö., M.D., B.F.K., Design: D.S.Ö., M.D., Data Collection or Processing: D.S.Ö., S.E., M.D., Analysis or Interpretation: D.S.Ö., S.Ü.D., B.F.K., Literature Search: D.S.Ö., S.E., S.Ü.D., M.D., Writing: D.S.Ö.

Conflict of Interest: No conflict of interest was declared by the authors.

Financial Disclosure: The authors declared that this study received no financial support.

\section{References}

1. Laird E, Ward M, McSorley E, Strain JJ, Wallace J. Vitamin D and bone health: potential mechanisms. Nutrients 2010;2:693-724.

2. Peterlik M, Boonen S, Cross HS, Lamberg-Allardt C. Vitamin D and calcium insufficiency-related chronic diseases: an emerging world-wide public health problem. Int J Environ Res Public Health 2009;6:2585-607.

3. Holick MF. Environmental factors that influence the cutaneous production of vitamin D1-3. Am J Clin Nutr 1995;61:638-45.

4. Zhang R, Naughton DP. Vitamin D in health and disease: Current perspectives. Nutr J 2010;9:65.

5. Isenring EA, Teleni L, Woodman RJ, Kimlin MG, Walpole $E$, Karapetis CS, et al. Serum vitamin D decreases during chemotherapy: an Australian prospective cohort study. Asia Pac J Clin Nutr 2018;27:962-7.

6. Wacker M, Holick MF. Vitamin D effects on skeletal and extraskeletal health and the need for supplementation. Nutrients 2013;5:111-48.

7. de La Puente-Yague M, Cuadrado-Cenzual MA, Ciudad-Cabanas MJ, Hernandez-Cabria M, Collado-Yurrita L. Vitamin D: And its role in breast cancer. Kaohsiung J Med Sci 2018;34:423-7.

8. Davis DD, Milner JA. Nutri genomics, vitamin D and cancer prevention. J Nutrigenet Nutrigenomics 2011;4:1-11.

9. Drake MT, Maurer MJ, Link BK, Habermann TM, Ansell SM, Micallef IN et al. Vitamin D insufficiency and prognosis in nonHodgkin's lymphoma. J Clin Oncol 2010;28:4191-8. 
10. Goodwin PJ, Ennis M, Pritchard KI, Koo J, Hood N. Prognostic effects of 25-hydroxyvitamin D levels in early breast cancer. J Clin Oncol 2009;27:3757-63.

11. Ren C, Qiu MZ, Wang DS, Luo HY, Zhang DS, Wang ZQ, et al. Prognostic effects of 25-hydroxyvitamin D levels in gastric cancer. J Transl Med 2012;10:16.

12. Wang D, Ve'lez de la Paz OI, Zhai JX, Liu DW. Serum 25hydroxyvitamin D and breast cancer risk: a meta-analysis of prospective studies. Tumor Biol 2013;34:3509e17.

13. Vaughan-Shaw P, O'Sullivan F, Farrington S, Theodoratou E, Campbell H, Dunlop M, et al. The impact of vitamin D pathway genetic variation and circulating 25- hydroxyvitamin D on cancer outcome: systematic review and meta-analysis. $\mathrm{Br} J$ Cancer 2017;116:1092.

14. Feldman D, Krishnan AV, Swami S, Giovannucci E, Feldman BJ. The role of vitamin $D$ in reducing cancer risk and progression. Nat Rev Cancer 2014;14:342e57.

15. Wulaningsih W, Sagoo HK, Hamza M, Melvin J, Holmberg L, Garmo H, et al. Serum calcium and the risk of breast cancer: findings from the Swedish AMORIS study and a meta-analysis of prospective studies. Int J Mol Sci 2016;17:1487.

16. Pineda-Moncusi M, Garcia-Perez MA, Rial A, Casamayor G, $\operatorname{Cos} \mathrm{ML}$, Servitja $\mathrm{S}$, et al. Vitamin $\mathrm{D}$ levels in Mediterranean breast cancer patients compared with those in healthy women. Maturitas 2018;116:83-8.

17. American Cancer Society (ACS). Breast Cancer Facts \& Figures 2013-2014. Atlanta: American Cancer Society, Inc., 2013.

18. Fu MR. Breast cancer-related lymphedema: Symptoms, diagnosis, risk reduction, and management. World J Clin Oncol 2014;5:2417.

19. Chachaj A1, Małyszczak K, Pyszel K, Lukas J, Tarkowski R, Pudelko $\mathrm{M}$, et al. Physical and psychological impairments of women with upper limb lymphedema following breast cancer treatment. Psychooncology 2010;19:299-305.

20. Vassard D, Olsen MH, Zinckernagel L, Vibe-Petersen J, Dalton SO, Johansen $C$, et al. Psychological consequences of lymphoedema associated with breast cancer: A prospective cohort study. Eur J Cancer 2010;46:3211-8.

21. Dell DD, Doll C. Caring for a patient with lymphedema. Nursing 2006:36:49-51.

22. Holick MF. Vitamin D deficiency. N Engl J Med 2007;357:266-81.

23. International Society of Lymphology. The diagnosis and treatment of peripheral lymphedema. 2009 Consensus document of the International Society of Lymphology. Lymphology 2009;42:51-60.

24. Shao $T$, Klein $P$, Grossbarda M. Vitamin $D$ and breast cancer. Oncologist 2012;17:36e45.
25. Welsh J. Vitamin D metabolism in mammary gland and breast cancer. Mol Cell Endocrinol 2011;347:55e60.

26. Shirazi L, Almquist M, Borgquist S, Malm J, Manjer J. Serum vitamin D (25OHD3) levels and the risk of different subtypes of breast cancer: a nested case-control study. Breast 2016;28:184e90.

27. Abbas S, Chang-Claude J, Linseisen J. Plasma 25- hydroxyvitamin $\mathrm{D}$ and premenopausal breast cancer risk in a German case-control study. Int J Cancer 2009;124:250e5.

28. Jacot W, Pouderoux S, Thezenas S, Chapelle A, Bleuse JP, Romieu $G$, et al. Increased prevalence of vitamin D insufficiency in patients with breast cancer after neoadjuvant chemotherapy. Breast Cancer Res Treat 2012;134:709-17.

29. Shin WK, Kim Z, Youn HJ, Cho J, Lee JE. Determinants of Plasma 25-Hydroxyvitamin D Concentrations among Breast Cancer Survivors in Korea. Nutrients 2018;10.

30. Powe CE, Evans MK, Wenger J, Zonderman AB, Berg AH, Nalls $\mathrm{M}$, et al. Vitamin D-binding protein and vitamin D status of black Americans and White Americans. N Engl J Med 2013;369:19912000.

31. Smoot B, Wong J, Cooper B, Wanek L, Topp K, Byl N, et al. Upper extremity impairments in women with or without lymphedema following breast cancer treatment. J Cancer Surviv 2010;4:16778.

32. Sezgin Ozcan D, Dalyan M, Unsal Delialioglu S, Duzlu U, Polat CS, Koseoglu BF. Complex Decongestive Therapy Enhances Upper Limb Functions in Patients with Breast Cancer-Related Lymphedema. Lymphat Res Biol 2018;16:446-52.

33. Velanovich V, Szymanski W. Quality of life of breast cancer patients with lymphedema. Am J Surg 1999;177:184-7.

34. Chachaj A, Malyszczak K, Pyszel K, Lukas J, Tarkowski R, Pudelko $\mathrm{M}$, et al. Physical and psychological impairments of women with upper limb lymphedema following breast cancer treatment. Psychooncology 2010;19:299-305.

35. Cemal Y, Pusic A, Mehrara BJ. Preventative measures for lymphedema: separating fact from fiction. J Am Coll Surg 2011;213:543-51

36. Hsieh E, Wang Q, Zhang R, Niu X, Xia W, Fraenkel L, et al. Vertebral fractures among breast cancer survivors in China: a cross-sectional study of prevalence and health services gaps. BMC Cancer 2018;18:104.

37. Gao X, Fisher SG, Emami B. Risk of second primary cancer in the contralateral breast in women treated for early-stage breast cancer: a population-based study. Int J Radiat Oncol Biol Phys 2003;56:1038-45 